\section{Introduction to psychosexual medicine}

The task of psychosexual medicine, including expert genital examination, is "to help the person first complete the job of expressing, and then hearing, their own story ${ }^{1}$ " (page 10). The emphasis through this textbook, produced by the Institute of Psychosexual Medicine (IPM), is demonstrated in compassionate case studies and thoughtful processes of reflection. The task is to examine the "here and now" of the clinician-patient encounter, while respecting the "there and then" of the client's history.

The Institute (www.ipm.org) now admits nurses, physiotherapists and other clinical professionals to undertake its programmes of education. This book will therefore be of value to clinicians who want to know more, especially about pathophysiological underpinnings of illnesses or conditions; the psychosexual impact these can have on the body, mind and relationships, and the ways in which psychosexual medicine can help. It would have been good to see the new, multiprofessional membership more clearly represented, however, in a text which at times was a bit "we doctors".

The text is accurate, supported by sound references and reads well, given certain caveats. Obviously, no one book can encompass all matters, and I was generally impressed by the inclusivity of the 27 chapters. Equally, I was somewhat disappointed by how so many chapters revolved around core themes of erectile dysfunction, vaginismus, dyspareunia and non-consummation, predominantly with cis-gender, straight people; in parts, there seemed to be an overemphasis on (arguably Freudian) notions of "penetration", coupling, in a life-long union. There was less emphasis on the joys, pleasures, meanings and fulfilment of non-penetrative sexual pleasure. The joys and pleasures of sex, a la Foucault's ars erotica, including transgressive queer and kink, could have had more profiling, and masculinist notions of "impotence" and feminism's critique of the female orgasm could have been discussed in more challenging ways. The numerous references to how beautiful, smart, tidy and prim clients looked left me wondering how they would deal with ugly people, or those not fitting this "nice" mould.

Despite a nodding reference to transgender, lesbian, gay and bisexual people, elements of the book perpetuate the myth of two genders, with a Freudian predilection for "normality". It also conflated sexual "preference" with "orientation". A true "queering" of this text would beneficially challenge some of the taken-for-granted assumptions about sex and its meanings. The linkage of old people (" 65 ") in a chapter on "approaching end of life" also seemed rather dubious, and some chapters left me feeling that a shove outside the box, or to queer the topics, might have broadened the appeal.

Study this book; it is a well-worth-it text, despite its omissions. Rather than wait almost 20 years for the fourth edition, however, this text could ideally do with a companion volume. A companion that brings in the other healthcare professionals the IPM now educates, and their clinical perspectives, and that attends to issues such as training chaperones to be IPM-relevant chaperones; the psychosexual aspects of abortion, offering more emphasis on male partners, too; female genital cutting/mutilation; post-traumatic stress disorder from genital torture or sexual violence and rape against, or witnessed by, victims of war and asylum seekers; thriving with sex and disabilities; physical changes over the life-course; commercial, recreational and regretted sex; chem sex, and issues for those who "shut up shop" but are now back open again, including people living with HIV, when \#UequalsU (Undetectable equals Uninfectious).

This textbook is essential for students of the IPM, and important as an ongoing resource for new and experienced IPM practitioners and seminar leaders. It has relevance across disciplines and professions, in health and social care, too. It is for all those who work with clients having various psychosexual needs, be these pathophysiological conditions, body/mind or mind/body related problems, and across the life-course.

\section{David Thomas Evans $\odot$}

Faculty of Education and Health, University of Greenwich, London SE10 9LS, UK

Correspondence to Professor David Thomas Evans, Faculty of Education and Health, University of Greenwich, London SE10 9LS, UK; D.T.Evans@greenwich. ac.uk

Twitter David Thomas Evans @David_T_ Evans

Funding The authors have not declared a specific grant for this research from any funding agency in the public, commercial or not-for-profit sectors.

Competing interests None declared.

Patient consent for publication Not required.

Provenance and peer review Not commissioned; internally peer reviewed.

(c) Author(s) (or their employer(s)) 2019. No commercial re-use. See rights and permissions. Published by BMJ.

\section{Check for updates}

BMJ Sex Reprod Health 2019;45:313. doi:10.1136/bmjsrh-2019-200453

ORCID iD

David Thomas Evans http://orcid.org/ 0000-0001-6874-3845

\section{REFERENCE}

1 Brough Phillipa A, Margaret D. Introduction to psychosexual medicine: third edition. Third Edition, 2019. ISBN: 9781138095786. 